This is author's self-archived version submitted for International Journal of Innovation and Technology Management for the final revision round.

Electronic version of an article published as International Journal of Innovation and Technology Management, [18, 1, 2021]

The final version of the article can be found at: $h$ ttps://doi.org/10.1142/S0219877020500480

Please see, and refer only to, the final version of the article.

Lehtimäki, T., \& Komulainen, H. (2021). Matching Co-innovation project types to diverse customer relationships: Perspective of an industrial technology supplier. International Journal of Innovation and Technology Management, 18(01), 2050048.

International Journal of Innovation and Technology Management, https://www.worldscientific.com/worldscinetijitm

Final version published by, and the holder of copyright for that version is, World Scientific Publishing Company. 


\title{
MATCHING CO-INNOVATION PROJECT TYPES TO DIVERSE CUSTOMER RELATIONSHIPS: PERSPECTIVE OF AN INDUSTRIAL TECHNOLOGY SUPPLIER
}

\begin{abstract}
Co-innovation between suppliers and their customers provides important benefits but is not without challenges. Especially in technologically complex industrial context coinnovation projects need careful planning and preparing. Through eight cases, this qualitative study takes the perspective of the supplier and empirically identifies three types of suppliercustomer co-innovation projects and for each project type, the supplier's co-innovation goal, potential matching customer relationships, and related managerial benefits and challenges are described. The results contribute to the co-innovation research by presenting a framework for matching supplier's co-innovation goals to customer relationship types, which brings out the variety of co-innovation projects that even a single supplier can face and must manage.
\end{abstract}

Keywords: Co-innovation management; case study; buyer-supplier collaboration; innovation management; supplier-customer relationship 


\section{Introduction: The Need to Distinguish Between Different Types of Supplier-Customer Co- Innovation Projects}

Companies are increasingly engaging in inter-organizational projects to exploit external resources, knowledge, and organizational learning to develop new products more efficiently and to enter the market with the most relevant innovations (Backmann et al. 2016; Eslami and Melander, 2019). Collaborative relationship between customers and suppliers have been recognized as highly important for new product development (e.g. Backmann et al., 2016; Wang and Li, 2017), contributing directly to product performance (Lau, Tang and Yam, 2010), and collaboration is becoming a key innovation strategy for firms (Hartley et al., 2013).

Previous research has shown that working together for innovation produces various benefits for both suppliers and customers. Customer contribution can be considered as a source of information or of new product ideas, or as active participation in developing and testing activities, whereas supplier's contribution is to provide solutions to the customer's needs (Eslami and Melander, 2019). This kind of inter-organizational collaboration may result in, for example, improving company's operational performance, collective efficacy, and innovation capabilities (Lau, 2011). Although the extant literature has discussed the methods and the benefits of innovating with customers (Franke, 2006; Fang, 2008), engaging in collaborative innovation exposes firms to different challenges such as complexities of task coordination, uncertainty in terms of the specific partners' contributions and potential conflicts of interest arising from divergent expectations and goals (Backmann et al. 2016). Particularly, Eslami and Melander (2019) identified three key uncertainties in collaborative new product development. First, technological uncertainty may lead to technical challenges and difficulties in managing external collaboration. Second, organizational uncertainty refers to lack of strategy and capability of firms to collaborate with external partners and as a result, companies' interactions may be compromised. Third, commercial uncertainty refers to whether the innovation is commercially feasible and able to compete in the market.

Considering these challenges and uncertainties, it is understandable, that collaborative innovation projects are found to be difficult to control (Bruce et al., 1995), requiring careful management to achieve the possible rewards (Wilson et al., 1995). To secure the gains and to mitigate the risks of co-innovation, partner selection has remained as an important question (e.g. Enkel et al., 2005b; DeFilippi and Roser, 2014). What complicates this matter in supplier-customer co-innovation is the embeddedness of co-innovation projects and supplier-customer relationships (see e.g. Ombrosi, Casprini, and Piccaluga 2019). Managing this combination is important both for the supplier and the customer, since failed co-innovation projects might harm working supplier-customer relationships. This problem can present itself differently depending on who has the business interest in selling the co-innovated outcome, and whose perspective is in focus. There already is knowledge of how customers can choose suppliers for their co-innovation projects and manage supplier portfolios in that respect (see e.g. Schiele, 2012; Slowinski et al., 2015) but similar understanding of those options from the innovating suppliers' perspective is still limited. Furthermore, in several sectors (such as in construction industry), suppliers have a remarkable role in technological development and innovation. By having deliberate collaboration strategies, suppliers may lower their dependency on users for innovation. Therefore, this study focuses on the perspective of a supplier who wants to 
innovate with its business customers (i.e. users) and who has the business interest in selling the coinnovated outcome.

Especially, in a technologically complex industrial setting, where trust and fluent cooperation are found to be important for efficient co-innovation (Slowinski et al., 2015), the established customer relationships are a natural starting point when a supplier is looking for co-innovation partners (Cusumano and Takeishi, 1991). It has been suggested that a concentrated customer base, which reflects strong customer-supplier relationships and high switching costs, increases the supplier's motivation to invest more in R\&D and become more innovative (Krolikowski and Yuan, 2017). In that way, it can offer innovative and well-fitted solutions for its customers, even strengthening the existing customer relationships. In the context of technologically complex industrial co-innovation, suppliers' innovation efforts often require inclusion of customers, as they need customers' insight and, in many cases, facilities to effectively test their ideas and solutions. Often customers in that context seek help for specific technological problems from their suppliers, and they are motivated to co-innovate because of performance improvements, price reductions, exclusive rights to the outcome for a limited time, or additional services and warranties (Greer and Lei, 2012). That forms a fertile ground for co-innovation: the supplier has an aim to develop a commercially potential new solution and often oversees the co-innovation project, and the customer offers its input in order to improve its processes (Oinonen and Jalkala, 2015).

In terms of matching co-innovation needs and partners, technology suppliers may have more options than their customers may have, as often customer firms have invested in some supplier's technology in the long run and find it difficult to change a technology provider. Even then, industrial companies have a limited set of customers who they can consider for cooperative innovation. In the extant supplier-customer co-innovation research, the importance of strong customer-supplier relationships for innovations has been widely acknowledged (Krolikowski and Yuan, 2017; Xue et al., 2018), and its benefits are well studied. However, as a downside of the close, long-term innovation relationships there can be relational over-embeddedness (Granovetter, 1973) implying that strong relationships with a limited set of external partners may lose value when situated in a complex industrial context. In addition, suppliers may be more willing to co-innovate with so-called preferred customers, who are important for the supplier due to technical, commercial, cultural, and/or historical reasons or have a key account status (Schiele, 2012). These characteristics of preferred customers reflect well the findings of previous research on the relevant characteristics of business customers when involving them in supplier innovation (see e.g. Greer and Lei (2012) for a review). In addition, suppliers might want to innovate with lead-user customers, who experience needs before other customers and are not only willing but also capable of contributing to product concepts and design (von Hippel, 1986). The downside is that the identification of lead users is challenging (Lüthje and Herstatt, 2004)

Besides long-term innovation partners, preferred customers or lead-users, previous literature has found suppliers to co-innovate within diverse customer relationships and have multiple forms for customer involvement in their co-innovation projects that differ in their degree of innovativeness (e.g. Lagrosen, 2005; Scaringella, Miles, and Truong, 2017). In addition, it has been noted that the goals of the supplier vary according to the nature of the customer relationship involved and what is being developed (Oinonen and Jalkala, 2015). Nonetheless, this diversity is not much dissected in the existing industrial supplier-customer co-innovation literature. Thus, there appears to be a gap concerning research on collaborative supplier-customer innovation that would more closely 
investigate the diversity of both co-innovation projects and customer relationships from the suppliers' perspective, and more specifically, how they can be matched and what kind of managerial implications these combinations bring. Better understanding of the potential match of co-innovation project and customer relationship types could help the supplier to plan and prepare for its different customer co-innovation projects. In addition, buying firms may need to understand the motives of their suppliers in order to become attractive partners for co-development, while suppliers benefit from such a typology to help them make better choices which customer to contact for a co-innovation proposal. In that way, the customer relationships could be less impacted by partner mismatches in co-innovation projects.

To target the existing gap, this study adopts the perspective of an industrial technology supplier and aims to develop a framework for matching the types of collaborative innovation projects with customer relationship types. The first research question is, what kinds of customer relationships are suitable for diverse co-innovation project types? The second research question is, what benefits and challenges relate to managing these diverse types of industrial supplier-customer co-innovation projects? To answer the research questions, a literature review on co-innovation processes and supplier-customer co-innovation relationships is presented, resulting in an analytical framework depicting elements of co-innovation projects and customer relationships for the empirical study. Thereafter, a qualitative eight-case study examines the phenomenon empirically. The derived results form a framework, which describes the types of supplier-customer co-innovation projects, as identified from the empirical data, including the supplier's co-innovation goal, types of customer involvement and customer relationships, and benefits and challenges experienced by the supplier related to managing each co-innovation project type. After summarizing the findings, conclusions and managerial implications are presented, as well as limitations and suggestions for further research.

This study contributes to the industrial co-innovation research by offering a frame for the suppliercustomer co-innovation project initiation and preparing in technologically complex industrial settings. Especially, the study presents an empirically derived classification for the supplier's coinnovation project types. The findings present the set of suitable customer relationships for each coinnovation project type; the customer relationship concerned does not need to be deeply bonded and longitudinal in all cases, and on the other hand, long-term and trust-based customer relationships are fit to simple as well as complex endeavours of co-innovation. However, there appears to be preferred customer relationship types and specific managerial insights for each co-innovation project type.

\section{Co-Innovating with Industrial Customers}

\subsection{Customer involvement in industrial innovation projects}

Co-innovation can be defined as the ideation, development and commercialization of innovative new offerings between organizations that actively and interactively work together (Buur and Matthews, 2008; Lehtimäki et al., 2012). The process of co-innovation borrows from new product development (NPD) process descriptions, since often in supplier-customer co-innovation the activities are not that different from internal innovation or product development (Alam, 2002), even though multiple actors participate. Based on synthesizing co-innovation studies utilizing multi-staged NPD process frameworks (e.g. Gruner and Homburg, 2000; Alam, 2005; Enkel et al., 2005a; Enkel et al., 2005b; 
Lagrosen, 2005; Fang, Palmatier and Evans, 2008), the co-innovation project includes here the stages of idea generation, concept development, product development, testing, and commercialization.

These stages of co-innovation projects are needed in describing the type of customer involvement in them. An understanding of the required form and intensity of customer involvement is important already when planning the project, as time and effort needed for coordinating and managing the involvement varies accordingly (Enkel et al., 2005). Companies seek to engage customers to innovate throughout the innovation projects (Carbonell, Rodríguez-Escudero and Pujari, 2009). Nonetheless, customer involvement has been found more beneficial at certain stages of co-innovation than at others (Gruner and Homburg, 2000). Especially ideation, concept development, and testing stages have been suggested as fruitful stages for customer involvement (Urban and von Hippel, 1988; Enkel, et al., 2005a; Lagrosen, 2005). Co-innovation as a concept can refer to different degree of customer integration into the process and to various methods for integration (Lagrosen, 2005; Franke, 2006; Fang, 2008). The number of stages or activities in which customer takes part can be described through the breadth of customer involvement, whereas the level of involvement is discussed through depth (Fang et al., 2008). Both the breadth and the depth can be described for the whole innovation project, for each stage, or even for individual activities inside a stage (e.g. Enkel et al. 2005a; Lagrosen, 2005; Fang, et al., 2008; Öberg 2010). Customers' involvement can show in various ways: they can initiate the process, act as informative co-developers and testers, and finally act as a buyer, user and/or marketer (Öberg, 2010).

Thus, we analyze the customer's involvement on a stage and on a project level to understand how customers are involved in different innovation projects and how this type of involvement relates to supplier's co-innovation goals. The supplier's ultimate goal is to commercialize the co-innovated outcome, and therefore the supplier needs to understand the whole co-innovation process, but the customer may focus on the stages that are relevant for its own goals (Oinonen and Jalkala, 2015). Then, the entity of the process and the project is largely in the hands of the supplier. This study aims to understand supplier's view on that entity of a co-innovation project by examining the combinations of supplier's goal, type of customer involvement and type of customer relationship, which often have been tackled in separate studies.

\subsection{Supplier-customer relationships in context of co-innovation}

As projects in general, co-innovation projects are temporally restricted entities that have certain goals and resources. However, co-innovation occurring within supplier-customer relationships necessitates a broader view than a single project and its outcome. The importance of developing social capital in form of supplier-customer relationships is brought out for example in context of project-based industrial solution business (Tuli et al., 2007). In such a context the project level and relationship level exist in parallel as even one project delivery can tie the parties together for a long time because of diverse post-project services, for example. Co-innovation projects add one layer to this whole: in addition to the commercial project deliveries and services between the supplier and the customer, the co-innovation projects between the parties can form a technological funnel of co-innovation that is linked and co-evolving along a relational funnel (Ombrosi, Casprini, and Piccaluga, 2019). The technological and relational funnel, in the best case, fuel up each other (Ombrosi et al., 2019). However, that becomes visible only if there is a series of co-innovation projects between the parties. 
In the context of co-innovation projects, this means that the nature of the relationship needs to be acknowledged as it may carry implications to the project. Previous research has aimed to identify the characteristics of suitable customers to involve in co-innovation, ending up with notions of the customer's motivation and qualification to innovate, motivation to cooperate, and suitability of their technical profile (e.g. Enkel et al., 2005; Tsou et al., 2015). While those stay relevant considerations, this study wants to put focus on the type of the customer relationship involved, and its suitability for diverse co-innovation efforts of the supplier.

Hence, in industrial supplier-customer co-innovation, co-innovation projects and supplier-customer relationships are embedded, bringing both positive and negative implications to co-innovation projects. Previous literature brings out the benefits of trust-based, longitudinal relationships in coinnovation. Trust is critical to partnership formation and to the future success of cooperation, and trusting behavior tolerates minor drawbacks in the relationship, but also expects the parties to respond to one another's needs (Blomqvist, 1997). The prior relationship history helps the co-innovation parties to gauge each other's trustworthiness and opportunistic intent (Athaide, Stump and Joshi, 2003). The influential customers with whom the supplier has had strong relationships tend to make the most effective contributions to co-innovation (Bonner and Walker Jr., 2004). Strong, embedded ties between a supplier and a customer enhance open knowledge sharing and the exchange of rich, complex information (Bonner and Walker Jr., 2004; Noordhoff et al., 2011). However, it has been suggested that such ties work the best when developing less innovative new products, because, if compared to the development of more innovative products, those benefit more from the exchange of detailed information concerning product ideas, problems, and evaluations (Bonner and Walker Jr., 2004). Thus, continuously innovating with the same partners may not only promote but also hinder innovativeness.

In addition, suppliers differentiate among customer relationships according to more vague relationship features than trust, length, or bond strength. Some customers are more attracting than others in the eyes of the supplier when comparing the previous outcomes gained in the customer relationships and the overall satisfaction of the supplier with its customers; the preferred customers may then receive favorable treatment such as privileged resource allocation (see e.g. Schiele et al, 2012). In that case the supplier may choose to invest in co-innovation with customers with whom it is satisfied and has good experiences in previous projects.

Overall, the customer relationships bring varied implications to co-innovation projects and partner selection. To grasp a more holistic view of ways to characterize supplier-customer relationships, we refer to a review by Tangpong et al. (2015), who divide the common attributes used in previous research to characterize types of business relationships into two main categories: power-dependence attributes (e.g., power, dependence, and transaction-specific investments) and relational attributes (e.g., trust, commitment, integration, and cooperative efforts). In general, typologies based on powerdependence seem to assume that the company's power-dependence position dictates its strategies and action plans. As an example of these, Cox (2001) proposes four power-based buyer-supplier relationship types: independence, buyer dominance, supplier dominance, and interdependence. Brito and Miguel (2017) also categorize buyer-supplier relationships based on power asymmetry and suggest that companies can adopt different forms of governance mechanisms ranging between two extremes: contractual and relational. Contractual governance is based on formal contracts, unilateral investments, and short-term gains whereas relational governance implies long-term agreements based 
on personal relationships and social norms, such as trust and mutual commitment. Goldberg and Schiele (2020) study buyers' innovation process with technologically dominant suppliers and emphasize the need of carefully designing the buyer-supplier constellation in co-innovation and that in such a situation, the traditional innovation process may not work properly. As dominance plays an important role in co-innovation relationships, it is acknowledged in this study, too.

Nevertheless, a majority of the extant supplier-customer typologies are based on relational attributes (Tangpong et al. 2015). One of the most often used buyer-seller typology focuses on cooperative/close (high relational content) versus adversarial/arm's length (low relational content) relationship dichotomy (Kim and Choi, 2015), being in line with the relationship distinctions made in the co-innovation literature. Various categorizations including a broader range of buyer-supplier types between these two relational extremes have been suggested over the years (for a review, see Tangpong et al., 2015). Common idea in the typologies based on relational attributes appears to be that different buyer-supplier relationships are suitable for different exchange circumstances. To conclude, it can be assumed that diverse supplier-customer relationships are suited for diverse coinnovation projects.

For the purposes of this paper, it is not relevant to use numerous diverse dimensions to categorize supplier-customer relationships but rather to understand the main characteristics that differentiate relationships in respect to their suitability for diverse co-innovation projects with the supplier. Therefore, we rely here on Lagrosen (2005), who adopts many of the abovementioned relationship attributes, and uses them to present three levels of relationships in his study exploring customer involvement in new product development. It is based on the conceptual model that aims at helping managers to assess what is happening in a relationship, what its effects are and how they should develop the relationship (Ford et al. 2003). That resonates with the aim in this study to understand how to plan and prepare for co-innovation projects with customers.

According to the Lagrosen's (2005) model, that is originally based on the IMP (industrial marketing and purchasing) theory, 1) actor bonds are links developed between individuals, characterized by trust, a sense of closeness, appreciation and perceived commitment that influence and are influenced by 2) resources and 3) the activities through which the resources are integrated (Ford et al. 2003). Based on the level of closeness between these aspects three kinds of relationships can be identified: transactional, facilitative, and integrative (Lagrosen, 2005). Firstly, transactional relationships involve no integration between supplier and a customer and in these relationships, the early stages of the co-innovation process should be weighted, the supplier being the main actor in innovation. That can be characterized as design for the customer. In facilitative relationships both parties are willing to invest in activity links and resource ties to increase the value of the relationship even though customers are still mostly interested in undifferentiated products at lower cost. Here the emphasis should be in the early and in the testing stage of co-innovation and occasionally in other stages, the customer taking more part in the design effort than in transactional relationships. That can be described as design with the customer. Finally, in integrative relationships customer expects benefits beyond those of lower costs. The supplier and the customer work together towards a common aim. In this kind of relationships, the involvement can be deep and happen in all stages, and the customer is active in the design effort. By using this categorization by Lagrosen (2005), it is possible to cover both relational and power-dependence attributes such as trust, resource integration, commitment and dependence that matter in co-innovation relationships. Various studies have used the scale from 
Lagrosen (2005) to measure customer involvement and agreed that customer involvement has a positive effect on product innovation (e.g. Lin, Chen and Chiu, 2010). However, a choice of any model carries also limitations. For example, Lagrosen does not take a stand on the length of the relationship and focuses on the ways of integrating customers in innovation processes. Acknowledging these limitations, we use the work by Lagrosen (2005) as a loose analytical frame for categorizing customer relationships.

Hence, previous research suggests that certain kind of customer relationships are suited for certain kind of customer involvement in innovation (Lagrosen 2005; Tran and Shiu, 2015). Vice versa, we assume that the supplier's goals and specific needs for customer involvement in a planned coinnovation project affect the customer selection for the project. For example, in some projects the supplier needs to finalize and verify the in-house solution design and its operation at customer's processes, and the supplier goes through its customer relationships suitable for this kind of involvement. A single actor can have differing goals in its cooperative relationships at different points of time (Corsaro and Snehota, 2011). That suggests that a single supplier-customer relationship may be suitable for diverse co-innovation projects, which would be an extension to the results presented by Lagrosen (2005). Therefore, there is a need to explore more closely the relationship between supplier-customer co-innovation project types and customer relationship characteristics.

\subsection{Analytical framework: linking project type to customer involvement and relationship}

Various typologies have been developed to classify and characterize different types of buyer-supplier relationships with the aim of providing analytical tools for assessing and managing them. Similarly, various studies present findings on how to involve customers in co-innovation. However, the managerial framework considering diverse types of co-innovation projects and their suitability for diverse customer relationships is still missing. Therefore, we build a loose analytical framework (Figure 1) that assumes a connection between the co-innovation goals of the supplier, the type of needed customer involvement, and the types of customer relationships involved in co-innovation. We use Lagrosen's (2005) typology to describe the type of customer relationships of the supplier and characterize customer involvement through breadth and depth (Fang et al., 2008). Co-innovation goals are assumed to set some preferences for customer involvement patterns. The effect between coinnovation goals and customer relationship types is mutual, as the selection of partners is affected by the goals, but the goals also are influenced by the co-innovation partner(s). Also, the type of customer relationship is assumed to impact on the ways in which the customer might be involved in coinnovation, and the type of expected customer involvement influences the type of customer relationship that could suit the co-innovation project in question. This framework will be used for the empirical analysis, which aims to understand, how suppliers can match diverse co-innovation goals to diverse customer relationships, and what managerial implications these combinations bring. 


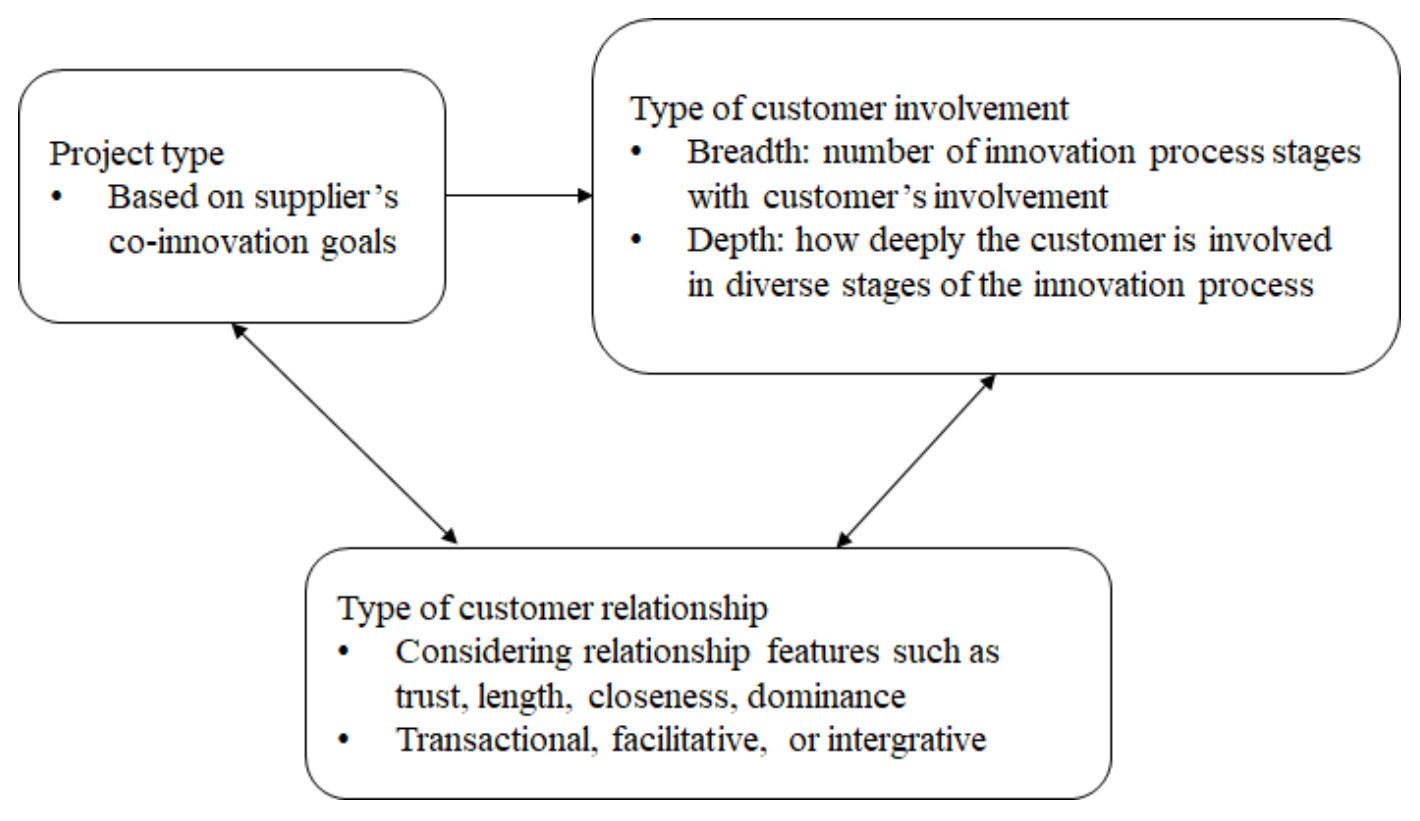

Figure 1. Analytical framework for matching co-innovation project types with customer relationship types.

\section{Methodology: A Multiple-Case Study}

A qualitative multiple-case study (Denzin and Lincoln 2000; Yin, 2009) explores eight co-innovation projects with varied duration, types and number of parties, goals of the participating organizations, the innovativeness of the outcome, and the marketability of the outcome. These projects occur between a Scandinavian supplier of technologically complex industrial solutions and its national and international customers, and in some cases, also with other parties; technology providers, research institutions and universities are often involved in such industrial co-innovation projects (e.g. Manotungvorapun and Gerdsri, 2019; Prabhu, 1999; Rajalo and Vadi, 2017). We acknowledge that often co-innovation happens in tight interaction in this kind of multiparty context. However, our focus is on understanding the supplier's view on the diversity of co-innovation projects and how they can match to the customer relationships of the supplier. Hence, a more networked and interactive view of co-innovation projects and relationships is beyond our focus at this point. We focus on one supplier that has rich and longitudinal experience in co-innovating with diverse customers in order to understand the variety of co-innovation projects that even a single supplier can face.

Qualitative methods support the purpose of this study to gain rich understanding of the complex phenomenon in its natural setting, when it is not reasonable to study the quantity, intensity or frequency alone (Denzin and Lincoln 2000: 8). The case study has been chosen as a research strategy to guide the choice of the study object and data collection procedures. A case refers here to a collaborative innovation project including a supplier and its customer(s); it is a natural object for the inquiry that is easily comprehended by the participants of this study.

The main data consists of sixteen personal interviews with the key participants of the examined projects (Table 1). Altogether nine customer organizations, one university, one research center, and 
two other development partners were involved in the examined projects with the supplier. Each case is described through one to five interviews, and through one to three organizations' perspectives, depending on the complexity of the examined project (Table 2). Having interviewees from other organizations than the suppliers help us to gain richer and deeper insight into the projects, even when our analytical viewpoint is of the supplier.

\section{Table 1. Interviewee information}

\begin{tabular}{|c|c|c|}
\hline Interviewee's organization & Interviewee's position & Case(s) discussed \\
\hline \multirow[t]{8}{*}{ The supplier } & 1. Product Manager, Expert Systems & Wireless process control system \\
\hline & 2. Sales Manager, Automation & Reporting tool \\
\hline & 3. Development Manager, Expert Systems & Simulation system for training \\
\hline & 4. Sales Director & Wireless process control system \\
\hline & 5. Automation Director & Courier on-stream analyzer \\
\hline & 6. Manager, Research \& Concept Development & On-line analyzer \\
\hline & 7. Technology director & Mixer \\
\hline & 8. Vice President R\&D & Froth camera B \\
\hline \multirow[t]{3}{*}{ Customer BP } & 1. Production Foreman & Wireless process control system \\
\hline & 2. Research Manager & Wireless process control system \\
\hline & 3. Operating Engineer & Wireless process control system \\
\hline \multirow[t]{3}{*}{ Customer P } & 1. Operating Engineer & Simulation system for training \\
\hline & 2.Plant Manager & Froth camera A, Froth camera B \\
\hline & 3. Safety Manager & Froth camera A, Froth camera B \\
\hline \multirow[t]{2}{*}{ University } & 1. Post-doctoral Researcher A & $\begin{array}{l}\text { Froth camera A, Froth camera B, } \\
\text { Simulation system for training }\end{array}$ \\
\hline & 2. Post-doctoral researcher B & Courier on-stream analyzer \\
\hline
\end{tabular}

Table 2. The main data for the cases

\begin{tabular}{|l|l|l|l|}
\hline $\begin{array}{l}\text { The supplier's co- } \\
\text { innovation project }\end{array}$ & \multicolumn{2}{|l|}{ Interviews } & Parties in addition to the supplier \\
\hline $\begin{array}{l}\text { 1.Wireless process control } \\
\text { system }\end{array}$ & 5 & $\begin{array}{l}2 \text { supplier interviews } \\
3 \text { customer BP interviews }\end{array}$ & Customer K, Customer BP, Customer BKo \\
\hline 2. Froth camera A & 3 & $\begin{array}{l}1 \text { university interview } \\
2 \text { customer P interviews }\end{array}$ & $\begin{array}{l}\text { Customer P } \\
\text { University }\end{array}$ \\
\hline 3. Froth camera B & 4 & $\begin{array}{l}1 \text { supplier interview } \\
1 \text { university interview } \\
2 \text { customer P interviews } \\
1 \text { supplier interview } \\
1 \text { university interview } \\
1 \text { customer P interview }\end{array}$ & $\begin{array}{l}\text { Customer P, Customer Ca } \\
\text { Development Partner Cr }\end{array}$ \\
\hline $\begin{array}{l}\text { 4. Simulation system for } \\
\text { training }\end{array}$ & 3 & $\begin{array}{l}1 \text { supplier interview } \\
1 \text { university interview } \\
1 \text { supplier interview }\end{array}$ & $\begin{array}{l}\text { Customer P } \\
\text { University }\end{array}$ \\
\hline 5. On-stream analyzer & 1 & 1 & $\begin{array}{l}1 \text { supplier interview } \\
\text { Customer Y, Customer BS }\end{array}$ \\
\hline 6. Mixer & 1 & $\begin{array}{l}\text { Development Partner B } \\
\text { Customer BKe } \\
\text { Research Center L }\end{array}$ \\
\hline 7. On-line analyzer & Cuptomer N \\
\hline 8. Reporting tool & &
\end{tabular}

The interviewees were recruited through snowball sampling (Biernacki and Waldorf, 1981). We started by interviewing a key person from the supplier that was involved in a recent co-innovation project. That informant provided names of other interviewees from the supplier and the customer firms and mentioned other interesting co-innovation projects of the supplier, which we then examined 
further. The interviews lasted about 90 minutes each and were recorded and transcribed. The interviewees represented different functions and organizational levels. The interviews cover the collaborative innovation activities of each partner, benefits and challenges experienced, and goals and results of the projects. In addition, available public data (such as news and announcements), and archival data (such as project files) of the cases were analyzed for data triangulation.

The qualitative content analysis followed abductive logic (Dubois and Gadde, 2002) and the stages of data reduction, data display and conclusion drawing (Miles and Huberman, 1994). The interviews were analyzed first separately, then on a case and on a project type level. Themes of project activities, project goals, project actors, project challenges, project benefits, and project results were analyzed from the data. All relevant information was put on a chronological order in order to write case stories. Diverse tables were drawn at this analysis phase to display the data among the themes used. Conclusion drawing focused on identifying relevant relationships between the themes to answer the research question. Next, the cases are presented briefly, which is followed by a summarizing analysis.

\section{Empirical Findings: Identification of the Co-Innovation Project Types}

The cases present a variety of co-innovation project types in terms of supplier's goals, project outcomes, customer relationships, constellation of actors and their involvement (Table 3). The starting point for the analysis of the cases was to categorize the co-innovation projects by the supplier's goals for co-innovation and three main categories were identified: customer testing, collaborative development and new knowledge. Even though customer involvement varied a lot, customers were important partners for all types of co-innovation projects. Based on our data, stages of idea generation, concept development and testing were the stages where customers were typically involved, supporting Urban and von Hippel (1988), Enkel, et al. (2005a), and Lagrosen (2005). In the examined projects, nearly all the customers were already users of the supplier's technology or products. There were customer relationships of several types; some very deep and long, whereas others had weak ties and a short history, but some level of trust was needed in all types of projects. Next, each project type is presented in more detail.

Table 3. Case descriptions

\begin{tabular}{|c|c|c|}
\hline Case & $\begin{array}{l}\text { Supplier's goal and } \\
\text { outcome }\end{array}$ & Description of the co-innovation project \\
\hline Mixer & $\begin{array}{l}\text { Goal and outcome: } \\
\text { Totally re-designed } \\
\text { commercially viable } \\
\text { product }\end{array}$ & $\begin{array}{l}\text { Customer testing focused co-innovation. Supplier-customer cooperation was } \\
\text { emphasized for testing and giving feedback. } \\
\text { The supplier, Customer Y and Customer BS cooperated for innovating new kind of } \\
\text { a mixer. These customers were well familiar with the supplier, and their goal was } \\
\text { to learn more about this new kind of mixer, and they had done co-innovation with } \\
\text { the supplier before. } \\
\text { The supplier was the main developer, and the testing Customers Y and BS were } \\
\text { more involved at the later phases, providing feedback, personnel, and facilities. } \\
\text { Customer Y was especially motivated and active since it had similar kind of a } \\
\text { development project going on. More customers took part in the second round of } \\
\text { tests. }\end{array}$ \\
\hline $\begin{array}{l}\text { Froth } \\
\text { camera B }\end{array}$ & $\begin{array}{l}\text { Goal: To have a } \\
\text { technologically new } \\
\text { solution quickly. }\end{array}$ & $\begin{array}{l}\text { Customer testing focused co-innovation/Collaborative innovation with a } \\
\text { development partner and a customer. Active co-innovation with a development } \\
\text { partner during the early phases; then involvement of two testing customers of } \\
\text { which other was more involved than the other. }\end{array}$ \\
\hline
\end{tabular}




\begin{tabular}{|c|c|c|}
\hline & $\begin{array}{l}\text { Outcome: } \\
\text { Commercially viable } \\
\text { new solution. }\end{array}$ & $\begin{array}{l}\text { The supplier wanted to develop a new product and did not want to do it from } \\
\text { scratch on its own. The project included co-innovation with Development Partner } \\
\text { Cr, with whom the supplier did not have any prior relationship but initiated one } \\
\text { through common acquaintances. } \\
\text { After the development interests of Development Partner Cr and the supplier started } \\
\text { to differentiate, the supplier bought the IPRs from Development Partner Cr. } \\
\text { Afterwards the project involved also testing Customers P and Ca, with whom the } \\
\text { supplier already had relationships. } \\
\text { Customer P was a co-developer and the first installation. Customer Ca was less } \\
\text { active in development but active in testing, and it also was the first reference } \\
\text { customer for the solution. Development Partner Cr was deeply involved in } \\
\text { development, wanting to develop their camera technology and know-how. } \\
\text { However, the development was led by the supplier. } \\
\text { Customer P was a long-term customer and co-innovation partner for the supplier; } \\
\text { other parties of the project were less so. }\end{array}$ \\
\hline $\begin{array}{l}\text { Wireless } \\
\text { process } \\
\text { control } \\
\text { system }\end{array}$ & $\begin{array}{l}\text { Goal and outcome: } \\
\text { Commercially viable } \\
\text { new solution }\end{array}$ & $\begin{array}{l}\text { Collaborative development. Co-innovation with diverse customers at different } \\
\text { stages of the project: some rather deeply involved in the beginning of the project, } \\
\text { some involved at the later stages of the project. } \\
\text { This project involved deep co-innovation, especially during idea generation and } \\
\text { concept development. The solution was ideated with Customer K, who was very } \\
\text { interested and proactive in developing the solution, and the solution combined } \\
\text { technology from both parties. } \\
\text { Later the supplier took over the development because it had better resources to do } \\
\text { that and it wanted to direct the development into a viable commercial product. } \\
\text { Customers BP and BKo were involved in testing later, and a supplier network was } \\
\text { established to carry out the final development and commercialization. } \\
\text { All customers were familiar with the supplier but not much involved in any earlier } \\
\text { co-innovation projects. }\end{array}$ \\
\hline & $\begin{array}{l}\text { Goal: Fast } \\
\text { development of a } \\
\text { new version of an } \\
\text { analyser, based on an } \\
\text { identified customer } \\
\text { need. } \\
\text { Outcome: } \\
\text { Commercially viable } \\
\text { new product. }\end{array}$ & $\begin{array}{l}\text { Collaborative development. Cooperation happened throughout the project, but } \\
\text { different actors were active at different stages. } \\
\text { The supplier, Development Partner B, Customer BKe and Research Center L were } \\
\text { the main co-operators in this project. } \\
\text { The supplier was the main actor throughout the project. Development Partner B } \\
\text { participated in concept development and solution development and brought in its } \\
\text { technology, as it was very interested in developing such a new solution and needed } \\
\text { a knowledgeable partner for that. IPRs were agreed with the supplier and the } \\
\text { Development Partner B on a formal contract. Long term Customer BKe } \\
\text { participated the concept development, solution development and testing, and its } \\
\text { interest was to improve its processes. } \\
\text { Research Center L was contacted for the further development of the analyser for } \\
\text { other contexts. A new research project was based on this project. }\end{array}$ \\
\hline $\begin{array}{l}\text { Reporting } \\
\text { tool }\end{array}$ & $\begin{array}{l}\text { Goal and outcome: } \\
\text { New tailored } \\
\text { reporting tool for a } \\
\text { single customer that } \\
\text { can be developed to a } \\
\text { customizable product } \\
\text { for a broader market. }\end{array}$ & $\begin{array}{l}\text { Collaborative development. Cooperation focused on concept development and } \\
\text { specification. } \\
\text { The project was a consultative sales project, which included co-innovation. } \\
\text { Supplier was the main actor and developer throughout the project, and Customer } \\
\text { N, who needed a new reporting tool, provided ideas and needs information for idea } \\
\text { generation and concept development. Testing at the customer site was not done } \\
\text { prior the delivery. } \\
\text { Customer N was not in a relationship with the supplier before this. }\end{array}$ \\
\hline $\begin{array}{l}\text { Froth } \\
\text { camera A }\end{array}$ & $\begin{array}{l}\text { Goal: To understand } \\
\text { better the technology } \\
\text { and its application. } \\
\text { Outcome: Features } \\
\text { for the supplier's } \\
\text { own solution. }\end{array}$ & $\begin{array}{l}\text { New knowledge development. Co-innovation occurred throughout the project } \\
\text { between three different types of organizations with diverse but matching goals. } \\
\text { Development continued over several projects. } \\
\text { This project involved co-innovation between the supplier, Customer P and } \\
\text { University to develop a new froth camera for Customer P's processes. } \\
\text { Customer P acted at some phases as an active developer and as a testing site, as it } \\
\text { had been developing a prototype with University a bit earlier, and at some phases }\end{array}$ \\
\hline
\end{tabular}




\begin{tabular}{|l|l|l|}
\hline & & $\begin{array}{l}\text { it acted mainly as an informer. University was an active co-developer and } \\
\text { coordinator of the project. The supplier was a co-developer throughout the project. } \\
\text { Customer P was a long-term customer and co-innovation partner for the supplier. } \\
\text { All parties were accustomed to co-innovate together. }\end{array}$ \\
\hline $\begin{array}{l}\text { Simulation } \\
\text { system for } \\
\text { training }\end{array}$ & $\begin{array}{l}\text { Goal: New product } \\
\text { Outcome: Insight } \\
\text { into and new features } \\
\text { for a training } \\
\text { simulation system, } \\
\text { piloted with some } \\
\text { customer trainings } \\
\text { wot with success). }\end{array}$ & $\begin{array}{l}\text { This project included the supplier, University and Customer P. The supplier was } \\
\text { the main developer, Customer P provided feedback and the real-life platform for } \\
\text { development and testing, and University was a co-developer and a coordinator. } \\
\text { Project received external funding. New features were developed for an existing } \\
\text { simulation software based on identified customer needs. New project was planned } \\
\text { based on this. } \\
\text { Customer P was a long-term customer and co-innovation partner for the supplier. } \\
\text { All parties were accustomed to co-innovate together. }\end{array}$ \\
\hline $\begin{array}{l}\text { On-stream } \\
\text { analyser }\end{array}$ & $\begin{array}{l}\text { Goal: New } \\
\text { knowledge of the } \\
\text { technology and a } \\
\text { new commercial } \\
\text { product. } \\
\text { Outcome: New } \\
\text { knowledge and a } \\
\text { prototype. }\end{array}$ & $\begin{array}{l}\text { of the project. } \\
\text { The supplier, Customer P and University co-innovated an on-stream analyser } \\
\text { utilizing Customer P's processes as a development and testing site. Customer P } \\
\text { provided feedback and insight into the practical problem, aiming to learn from the } \\
\text { technology and possibly getting a new kind of analyser to be used. University was } \\
\text { the main coordinator. The supplier was the main actor in co-innovation. Part of the } \\
\text { funding was from external sources. A university was involved in idea generation } \\
\text { and development. } \\
\text { Customer P was a long-term customer and co-innovation partner for the supplier. } \\
\text { All parties were accustomed to co-innovate together. }\end{array}$ \\
\hline
\end{tabular}

\subsection{Customer testing projects: verifying supplier-developed solutions in a customer application}

In customer testing projects, the supplier has an idea for some new solution, which it develops quite far, and the main need for customer involvement is to verify and test the solution at customer facilities. Typically, the supplier dominates in this type of co-innovation projects and controls the direction of the development work. The cases of Froth camera B and Mixer represent this type of project. Customers provide feedback, testing facilities, personnel, and sometimes part of the funding for the project. Customers who have interest and knowledge to develop the product, can be more deeply involved and offer ideas and feedback at the ideation and concept development phases, or even participate in development activities or marketing the solution as a reference site. Often customers can buy the solution for a lowered price, or the supplier cannot sell the solution to other customers for a while. In addition, customers are motivated by the potential process improvements and competitive advantage the new solution is expected to bring. There can be several customers involved, representing different types of customer facilities or market areas, for example. Also, often customers involved in this type of projects already have an installed base of the supplier's technology, especially when the co-innovated solution being tested integrates to existing technological systems.

This type of co-innovation is irreplaceable for the supplier, as real scale testing is a prerequisite for well-functioning, technologically complex industrial solutions. The supplier needs customer's insight into operating the solution and the related practical problems and usability. The main benefit of this type of a testing-focused project is that it makes the product's way to the market faster and easier, with less technical problems, compared to a situation where in-house developed product is directly launched for broader sales. Typically, this kind of projects do not create IPR conflicts since it is clearly the supplier, who provides its technological knowledge and input for the actual development. 
When the idea of the solution and its technical design is rather clear for the supplier, the customer relationship can be without close bonds or long history, making many kinds of customers suitable for these projects. Therefore, it is easier to involve more customers, which can accelerate the build-up of a convincing reference portfolio and bring in fresh insights. As well as in co-innovation in general, the parties must have a mutual positive attitude and good will in their relationship, so that there is a necessary level of trust; the supplier does not mess up with customer's processes, delivers what is promised, and the customer does not spread confidential knowledge and is willing to cooperate throughout the tests.

Even though it might sound like the customer is not that deeply involved in this type of a project, the testing phase requires quite much customer effort, commitment, and time. "The customer is in a central role when we are at the stage where we have some idea that we want to try out, (...). And it is very important - the tests can last for a long time - that the customer provides resources. Their engineering department can do some design and implementation tasks, so that the equipment can be installed as needed. Their own maintenance organization or instrument department can be in a remarkable role in using and maintaining the equipment." (Supplier's Automation Director). Hence, the relationship must endure some uncertainty, and calls for mutual effort and investments.

Because commitment and interest of the customer was seen central to project success, it pays off the effort to find the right persons from customer organizations to create such commitment: "It might be worthwhile to (...) search for (...) that kind of persons from the customer organization, who understand that this can bring remarkable financial benefits for them if it works. And to get the customer committed from the beginning. That would bring results remarkably faster in some cases. Especially so, that we do not need to push that much but the customer would help more all the time through the whole process." (Supplier's Technology Director). Naturally, identification of such persons might happen easier with familiar partners.

Personnel at the testing facility needs to be informed about the tests well beforehand and motivated, to avoid problems when difficulties emerge. Problems in testing might lead to overall negative attitude toward the new solution and create negative word-of-mouth. Customers wish supplier's presence at their facilities throughout the testing period. That benefits the supplier, too, as the supplier can make sure that tests run smoothly, and necessary documentation is done to prove the expected process improvement. The supplier must pay attention to the post-project phase, too: maintenance and updates for the system must be agreed on and the situation, where the customer is left alone with a poorly functioning prototype at their facilities, must be avoided.

\subsection{Collaborative development projects: innovating commercially viable new products}

In collaborative development projects, the supplier has a product in mind that it wants to develop, for example, to answer a raised customer need or a competitive situation. The supplier's aim in these projects is to innovate a commercially viable new product. The supplier involves development partners to the project in order to gain insight into the practical problem, technological know-how, or to speed up the development, for instance. Customers, universities or other technology providers are all potential partners for these projects. Cases of Froth camera B, Wireless process control system, On-line analyzer, and Reporting tool represent this type of co-innovation, each having a bit different constellation of parties. 
In this type of a co-innovation project, customers can be involved in more stages and in a deeper manner than in customer testing projects. Accordingly, keeping in touch with the customer requires a lot of effort, and the whole project group of the supplier might benefit from familiarizing themselves to the customers' processes to improve customer communication as well as the design. The customer is good to have technological knowledge so that it understands and identifies its technological needs, so that the supplier does not have to put effort on that discussion in the beginning of the project. However, highly knowledgeable customers might also bring challenges and complicate the project, as they may have strong interests in and aims for directing the technological development.

Typically, the supplier is leading the development, especially in the stages closer to commercialization of the solution, because it wants to secure the commercial viability of the solution. However, active development partners or customers might have a remarkable position, if not dominance, in the earlier phases of the project. All parties might not be involved throughout the project. These projects might have several customers involved; others more involved in the development stage and others in testing. Customers are motivated by the improvements that the new solution might bring to their processes and they do not wish to be bystanders but actively involved in innovating. In cases of Froth camera B and Wireless process control system, there was active coinnovation during the whole project, but the supplier took over the development later to secure the continuance and direction of the development, and the parties changed when the development turned into testing activities.

In this type of projects, the customer relationships involved are rarely new, but can be, when other conditions match. In Froth Camera B case, Development Partner Cr, rather unknown for the supplier, was an active and a very motivated developer of the solution. "It is faster, because - especially in this case - the other party is extremely excited, agile, and takes the development out of our hands; they push it. If we would have overtaken the development, it would have lasted a lot longer to have...I don't know...that drive. Or the drive might have been found but not the time. In larger companies, many good things get buried." (Supplier's Manager - Research \& Concept Development). Thus, when the development goal is rather clear and the need for a new solution is urgent, longitudinal customer relationships are not a necessity for collaborative development, but as an interviewee put it: "In any case, you must create trust-based relationships, before any kind of cooperative development can happen. (...) It means, on a personal level. (...) Firms can be anything but if there is no chemistry between them, nothing happens" (Supplier's Manager - Research \& Concept Development). However, especially in this kind of projects, and with new partners, ownership of IPRs and post-project issues need to be agreed on in the beginning of the project, since the development partners and customers contribute to the actual development

\subsection{New knowledge development projects: exploring and researching new technologies}

The aimed project outcome is not always a commercial new product ready for sales, but some projects are more explorative and research oriented, aiming at learning about a technology, for example, to be used in later projects. These projects can include a variety of actors, usually research institutions such as universities or commercial laboratories, in addition to customers. Customers offer the context and knowledge for the researched phenomenon, and the facilities for the practical part of the coinnovation effort. Universities can act as coordinators of such research-oriented projects. Hence, in this type of project the supplier can have a more balanced position among other parties as compared 
to other project types. The supplier is an active co-innovator throughout the project, offering its expertise and development resources for the project. The level of activity by customers and universities vary, but in general, they are more involved in the project than in the testing focused projects. The common aim of the parties is to learn about new technologies and solutions, and direct commercial benefits are expected in the longer run than in the other co-innovation project types.

Froth camera A, simulation system for training, and on-stream analyzer cases represent this type of a project. Parties in all these projects happen to be the same; the supplier, Customer P and University. These parties have a long, shared history of all types of co-innovation projects and Customer $\mathrm{P}$ is a long-term customer of the supplier. However, in this type of co-innovation, where the technological and business uncertainties are high in respect to what is eventually gained, trust-based, deeply bonded relationships are particularly essential, reducing the organizational uncertainty. The benefits and challenges are weighted against a longer period than a single project. When there are multiple successful co-innovation projects, the relationship gets stronger, and it is possible to do deeper, broader and riskier innovation projects together. Even though long-term co-innovation relationships bring benefits, they need to be kept fresh: "Yes, a long customer relationship makes things easier, but then you can ask that are we stuck to certain patterns in our cooperation." (Supplier's Sales Director).

External funding from public or industry sources is often acquired for such projects. For the supplier, such projects offer decreased financial risks for technological learning. The negative side is that the project might get overly driven by the participating customer's problems or a specific research interest, when the supplier might find it difficult to apply the results commercially. Therefore, the supplier must stay active throughout the project to influence on the direction of the research interest.

When the result is not a fully functioning new product at the customer's site but maybe a prototype, it is still important to agree on post-project development and maintenance. In this type of projects, formally agreeing on IPR ownership requires special attention, even when the parties are familiar with and trust each other. When a university brings in its technological knowledge and is an active ideator and developer, it might have interest in owning the IPRs.

\section{Discussion and Conclusions}

\subsection{Summarized typology of supplier-customer co-innovation projects}

The main empirical findings of the study identified and described three co-innovation project types, including supplier's co-innovation goals, customer involvement and relationship types, and the diverse benefits and challenges for the supplier related to managing each project type. These are summarized in Table 4. Having the supplier's goals as a starting point for the co-innovation project typology provided several interesting results as it made it possible to clarify the role of different types of customer relationships in each project type. There appears some common characteristics across the project types, but there are important distinctions, too. For example, some initial level of mutual trust or basis for trust building is needed in all co-innovation projects, since there is exchange of critical information, and technological and financial risks for both parties. Also, suitable knowledgebase and available resources for co-innovation are necessary preconditions for coinnovation projects. What comes to the differences, the position of the supplier was different in each project type and accordingly, there appears diverse managerial benefits and challenges. 
Table 4. Typology for supplier-customer co-innovation projects

\begin{tabular}{|c|c|c|c|}
\hline $\begin{array}{l}\text { Co-innovation } \\
\text { project } \\
\text { characterization }\end{array}$ & Customer testing projects & $\begin{array}{l}\text { Collaborative development } \\
\text { projects }\end{array}$ & $\begin{array}{l}\text { New knowledge } \\
\text { development projects }\end{array}$ \\
\hline Supplier's goal & $\begin{array}{l}\text { To verify a new in-house } \\
\text { developed solution at } \\
\text { customer facilities } \\
\text { To receive customer feedback } \\
\text { on a supplier's solution }\end{array}$ & $\begin{array}{l}\text { To acquire external insight, } \\
\text { technological knowledge and } \\
\text { resources for (fast) } \\
\text { development of a new } \\
\text { commercial product }\end{array}$ & $\begin{array}{l}\text { New technological knowledge } \\
\text { and learning to be used in } \\
\text { other projects } \\
\text { A commercial product, or } \\
\text { features for such, might be an } \\
\text { outcome but not necessarily a } \\
\text { major goal }\end{array}$ \\
\hline $\begin{array}{l}\text { Type of } \\
\text { customer } \\
\text { involvement }\end{array}$ & $\begin{array}{l}\text { Not broad, not very deep } \\
\text { Customer acts as a resource } \\
\text { and a feedback provider at the } \\
\text { testing phase, possibly also } \\
\text { gives feedback at earlier } \\
\text { phases, and can act as a } \\
\text { reference site }\end{array}$ & $\begin{array}{l}\text { Can be broad and deep } \\
\text { Customers are involved in } \\
\text { ideation, concept } \\
\text { development, and testing, and } \\
\text { sometimes in solution } \\
\text { development. Different } \\
\text { customers might be involved } \\
\text { in development than in } \\
\text { testing. } \\
\text { Development parties other } \\
\text { than customers can participate } \\
\text { throughout the project, even } \\
\text { initiate and lead the } \\
\text { development work, especially } \\
\text { in the first half of the project }\end{array}$ & $\begin{array}{l}\text { Often broad and deep } \\
\text { Customers are involved in } \\
\text { ideation, concept } \\
\text { development, and testing, and } \\
\text { sometimes in solution } \\
\text { development. } \\
\text { Research institutes can act as } \\
\text { project coordinators, initiating } \\
\text { and leading the development } \\
\text { work, and as co-innovators } \\
\text { before the commercialization } \\
\text { stage }\end{array}$ \\
\hline $\begin{array}{l}\text { Customer } \\
\text { relationship } \\
\text { types }\end{array}$ & $\begin{array}{l}\text { Transactional, facilitative or } \\
\text { integrative } \\
\text { At minimum, some level of } \\
\text { trust, personal level } \\
\text { matchmaking, suitable } \\
\text { resources, and mutual positive } \\
\text { attitude required }\end{array}$ & $\begin{array}{l}\text { Facilitative, integrative } \\
\text { Requires trust-based } \\
\text { relationships, preferably long- } \\
\text { term partners, or alternatively, } \\
\text { a good match in some other } \\
\text { respect (similar interests and } \\
\text { aims, suitable knowledgebase, } \\
\text { personal level bonding) }\end{array}$ & $\begin{array}{l}\text { Integrative } \\
\text { Requires trust-based, deeply } \\
\text { bonded relationships with } \\
\text { knowledgeable, long-term } \\
\text { partners, enduring uncertainty } \\
\text { and looking for long-term } \\
\text { benefits }\end{array}$ \\
\hline $\begin{array}{l}\text { Benefits for the } \\
\text { supplier related } \\
\text { to managing } \\
\text { these projects }\end{array}$ & $\begin{array}{l}\text { Dominated by the supplier, } \\
\text { making it less complex to } \\
\text { direct the co-innovation effort } \\
\text { towards an outcome useful for } \\
\text { the supplier } \\
\text { Can offer necessary customer } \\
\text { insight, feedback, and testing; } \\
\text { accelerate the innovation } \\
\text { process; improve the quality } \\
\text { of the product, and help to } \\
\text { acquire references for the new } \\
\text { product } \\
\text { Can be done with a variety of } \\
\text { customers } \\
\text { IPR conflicts are uncommon }\end{array}$ & $\begin{array}{l}\text { Many possibilities to build up } \\
\text { the constellation of partners } \\
\text { Easy to work with familiar } \\
\text { partners } \\
\text { External knowledge, } \\
\text { resources, ideas and feedback } \\
\text { can speed up and be vital for } \\
\text { the development } \\
\text { Learning from external } \\
\text { development parties } \\
\text { Testing with customers } \\
\text { improves the quality of the } \\
\text { product }\end{array}$ & $\begin{array}{l}\text { Easy to work with long-term, } \\
\text { trusted partners } \\
\text { Access to leading edge } \\
\text { knowledge } \\
\text { Deep learning in a real-scale } \\
\text { customer context } \\
\text { External funding can decrease } \\
\text { financial risk }\end{array}$ \\
\hline $\begin{array}{l}\text { Challenges for } \\
\text { the supplier }\end{array}$ & $\begin{array}{l}\text { Requires a lot effort from the } \\
\text { customer; the supplier needs }\end{array}$ & $\begin{array}{l}\text { Development partners and } \\
\text { customers might dominate the }\end{array}$ & $\begin{array}{l}\text { University or other research } \\
\text { institutions and customers }\end{array}$ \\
\hline
\end{tabular}




\begin{tabular}{|c|c|c|c|}
\hline $\begin{array}{l}\text { related to } \\
\text { managing these } \\
\text { projects }\end{array}$ & $\begin{array}{l}\text { to inform, motivate, and } \\
\text { support the customer } \\
\text { Need to monitor the tests to } \\
\text { take care of the customer } \\
\text { relationship, and test success } \\
\text { and documentation } \\
\text { Customer relationship must } \\
\text { endure uncertainty and } \\
\text { problems } \\
\text { A variety of testing customers } \\
\text { needed to represent diverse } \\
\text { facilities and markets } \\
\text { Agreeing clearly on post- } \\
\text { project updates, maintenance, } \\
\text { etc. }\end{array}$ & $\begin{array}{l}\text { early phases of the project, } \\
\text { which might complicate the } \\
\text { achievement of the supplier's } \\
\text { goals } \\
\text { Need to assure the } \\
\text { commercial potential of the } \\
\text { developed solution, and for } \\
\text { that purpose, potentially need } \\
\text { to overtake the development } \\
\text { from other parties at some } \\
\text { point } \\
\text { Parties often vary along the } \\
\text { process } \\
\text { Diverse interests of } \\
\text { development partners } \\
\text { The customer needs to have a } \\
\text { suitable level of technological } \\
\text { knowledge } \\
\text { Requires effort in customer } \\
\text { communication } \\
\text { Resources and commitment of } \\
\text { the development partner(s) } \\
\text { must be assured } \\
\text { IPRs need to be agreed on } \\
\text { clearly and formally, } \\
\text { especially with partners that } \\
\text { have contributed to the } \\
\text { development } \\
\text { Agreeing early on post- } \\
\text { project updates, maintenance, } \\
\text { etc. }\end{array}$ & $\begin{array}{l}\text { might have a strong position } \\
\text { or even dominate in this kind } \\
\text { of projects, and therefore, the } \\
\text { supplier needs to monitor the } \\
\text { commercial applicability of } \\
\text { the results } \\
\text { To keep established long-term } \\
\text { co-innovation relationships } \\
\text { innovative and fresh } \\
\text { Agreeing early on IPRs as } \\
\text { several parties contribute } \\
\text { actively to development } \\
\text { Agreeing early on post- } \\
\text { project development and } \\
\text { maintenance }\end{array}$ \\
\hline
\end{tabular}

The findings related to the identified co-innovation project types and the potentially suitable customer relationship types for them are illustrated in Figure 2, where lines connect these potential matches. Compared to Lagrosen (2005), our assumption about the more flexible use of diverse customer relationships to different types of co-innovation projects was supported but with some limitations. Even though some project types are suitable for many types of customer relationships, there appears to be one type of customer relationship for each project type that provides the best match. 


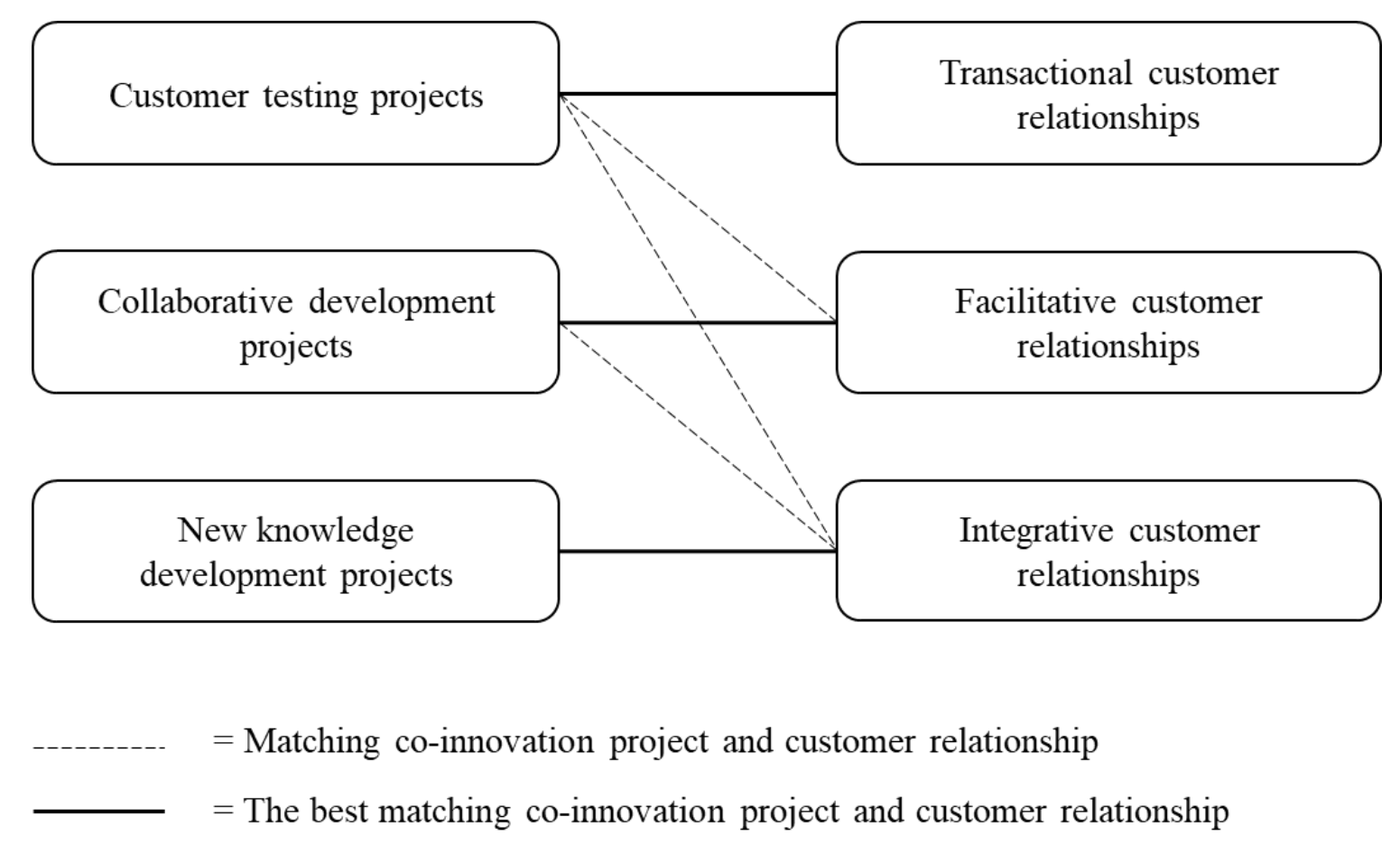

\section{Figure 2. Matching co-innovation project types with diverse customer relationships}

The findings show that within integrative relationships, with knowledgeable, long-term, trusted partners, all types of co-innovation projects are possible; not only projects requiring deep and broad involvement and strong trust. The identified importance and benefits, as well as drawbacks, of innovating with familiar co-innovation partner-customers were in line with previous research (Athaide and Stump, 1999; Tuli et al., 2007; Füller, Hutter and Faullant, 2011). This kind of longterm co-innovation partners are the only customer relationship type suited for new knowledge development projects with high uncertainties. Joint problem solving, communication and feedback giving is efficient when the parties know and understand each other, and these long-term customers are often geographically and culturally close. That makes the cooperation fluent. However, as noted, continuously innovating with same partners might make the outcomes less innovative and partners stick to routines, so there is a challenge of keeping these relationships fresh.

Within facilitative customer relationships, collaborative development projects are especially suitable, since that kind of projects do not require deep bonds and strong trust, but still the customer can be rather actively involved in the project. Customer testing projects are also possible within facilitative customer relationships. In collaborative development, other development partners than customers have a remarkable role, too, which is understandable as they provide important knowledge and capabilities for innovative development work. Management of the changing constellation of various active parties might be challenging for the supplier, who is not even always in the dominant position throughout such co-innovation projects.

In transactional, loosely bonded relationships, customer testing projects are the most suitable option, since customer's involvement to the project is not broad or deep, and the projects are more straightforward and more dominated by the supplier than other project types, making trust and 
bonding less critical. The customer testing projects can occur even in new relationships, as a sidetrack emerging from the first business case between the parties, for example.

Diverse co-innovation projects provide suppliers with multiple benefits and challenges that are already rather well covered by extant research (see e.g. Greer and Lei, 2012), but our findings summarize them from the supplier's perspective and help the supplier to get prepared to the managerial cons and pros that each project type might bring. Access to customer's knowledge, resources and facilities were the main elements of the benefits, leading to accelerated co-innovation projects, better quality of the developed product, and learning. On one hand, the familiarity of partners decreased the need for formal contracts in co-innovation, but on the other hand, agreeing on IPRs became more important as the development effort and knowledge input by other parties grew; typically, also the position of the other parties is stronger when their development effort grows in a project. Brito and Miguel (2017) separated contractual (control) and relational (trust and commitment) governance mechanisms. Based on our findings, the strong relationship does not exclude contractual mechanisms, but the effort of parties influences the importance of contracts, at least in the area of IPRs.

A common challenge for all project types was that post-project practices need to be clearly agreed on with the customer to avoid harm to the customer relationship, but otherwise the managerial challenges differed among the project types. Constant communication with customers and other partners is essential in all types of projects but in customer testing and collaborative development projects, where the customer might not be that involved in the project, supplier's presence at the customer facilities and communication with the customer needs special effort. Also, suppliers have different ways to assure the broad commercial potential of the new solutions or research results in different types of projects. In customer testing projects, broad selection of testing customers supports that aim, in cooperative development projects, the supplier often overtakes the whole development at some point, and in new knowledge development projects the supplier needs to monitor the course of the research or development continuously. That has a direct link to the question of who is dominating the coinnovation project. In customer testing projects, the supplier is usually directing the development work, whereas in collaborative development projects a customer or a development partner might be leading the development work in the earlier stages of the project. In new knowledge development projects, the supplier might not be in a dominant position at all.

\subsection{Theoretical contribution: three types of projects matching specific customer relationship types}

This study aimed to develop a framework for matching the type of collaborative innovation projects with customer relationship types to support the supplier in planning and preparing for such coinnovation projects. As a result, we identified three types of co-innovation projects: customer testing, collaborative development, and new knowledge development, and presented how they matched with transactional, facilitative, and integrative customer relationships (Figure 2). The co-innovation

project type included description of supplier's co-innovation goals, customer relationship characteristics, and customer involvement, and the related managerial benefits and challenges for the supplier (Table 4).

This study contributes to supplier-customer co-innovation research by offering a frame for the supplier for planning and preparing for customer co-innovation projects in technologically complex industrial settings. Even if the benefits and challenges of supplier-customer co-innovation are already 
rather well addressed in the literature (see e.g. Geer and Lei, 2012), we formulated a typology for such co-innovation projects, pointing out the multitude of customer co-innovation efforts a supplier can have and needs to manage. The study describes the diverse characteristics and managerial implications of each type, that have been neglected in the previous co-innovation studies.

Supplier-customer co-innovation projects were categorized here based on supplier's co-innovation goals instead of the more typical approach of using the type or level of customer involvement (e.g., Urban and von Hippel, 1988; Enkel, et al., 2005a; Lagrosen, 2005; Fang et al., 2008). Using goals and the types of available customer relationships as a starting point emphasized the supplier's viewpoint, helping suppliers to manage and plan their portfolio of co-innovation projects. Öberg (2010) and Davis and Eisenhardt (2011) have discussed the changes in supplier and customer roles in co-innovation processes. Our findings add to that understanding by showing how customer and supplier involvement may vary across co-innovation projects.

In addition, we clarified the relationships between co-innovation project types and suitable customer relationship types. Explicit presentation of these matches brings insight into the previous notion of the potential link between project types and customer relationship types (Oinonen and Jalkala, 2015). Lagrosen (2005) suggests that the level of relationships dictates the type of customer involvement. However, our findings implicate that the relationship type does not limit the suitability for diverse co-innovation projects that directly but that the more deeply bonded the relationship is, the more there are options for co-innovation. We also bring out the other possible parties involved in different supplier-customer co-innovation projects, such as research organizations, and their type of involvement in diverse types of co-innovation projects. The findings also show how the degree of supplier's dominance in a project is dependent on the co-innovation project type, not so much on the supplier's position in the customer relationship involved (Cox 2001) or on the supplier's technological position in the market (Goldberg and Schiele, 2020).

\subsection{Managerial implications: importance of the project type in planning co-innovation projects}

The findings of this study highlight the importance of the project type in planning co-innovation projects with customers, and managers of co-innovation projects could benefit from familiarising themselves with the potential benefits and challenges linked to each co-innovation project type identified in this study (see Table 4). Our study assumes the situation where the supplier is in a position to choose which customers to initiate co-innovation with, but sometimes the situation can be opposite, and the supplier evaluates whether to accept the initiative. However, the same principles can be used by the supplier for deciding on the co-innovation initiative in both situations. Although we focus here on customer selection, also other parties, such as research institutions and other development partners, can have important roles in the co-innovation projects.

More specifically, our study proposes several aspects the supplier needs to consider when choosing potential partners for co-innovation. The first managerial proposition (MP1) suggests that the supplier needs to define its own goals for the co-innovation project and use them as a key in which types of customers to cooperate with. In other words, whether the supplier needs verification through customer testing, collaborators for the development of a new commercial product, or new technical knowledge, affects further choices for co-innovation. Secondly, customer selection is further influenced by the type of customer involvement required in different phases of the co-innovation process, according to the goal of co-innovation. Therefore, MP 2 puts forward that the supplier needs 
to assess if the customer is willing and able to be involved in all the phases of the co-innovation or only some parts of it, and this affects the choice. Here the customer's technological know-how, motivation, trustworthiness, location, and representativeness in its business field need to be evaluated. Thirdly, besides the aforementioned viewpoints for customer evaluation, the nature of the customer relationship strongly influences its suitability for a specific type of co-innovation project. Does the relationship provide solid foundation for fluent communication, cooperation, and for facing technical difficulties and even failures? Thus, MP3 brings forward that the type of the customer relationship (transactional, facilitative, integrative) needs to be recognized in customer selection as it influences the customer's suitability for diverse co-innovation projects. Finally, the findings show that the type of the co-innovation project often influences strongly on who is leading the development work: a supplier, a customer or some other party. MP4 emphasizes that the supplier needs to consider beforehand who will be the likely dominant party in the project as it influences the measures how the supplier can support the achievement of its goals throughout the project.

\subsection{Limitations and suggestions for further research}

We acknowledge that the success of customer integration is more complex than the choice of the most suitable customer, including elements such as supplier firm's resources and capabilities (e.g., Schweitzer, Van de Hende and Hultink, 2018), and there are often other participants as well. The findings of this study can be applied to suppliers harnessing customer co-innovation in technologically complex industrial contexts, especially in solution business. Applying results beyond the described context should be done with care. Naturally, examination of more suppliers from other industries could refine the framework. However, the examined supplier was an experienced coinnovator, and through conceptualization, and links to previous research, the findings are taken to a higher analytical level than the immediate empirical context. For example, the co-innovation goals are applicable to diverse firms. Moreover, we used snowballing as a sampling method, which might come with risks such as sampling bias and a higher margin of error. As a next step for this exploratory study, a survey could be conducted to quantify and complement the findings, including both the views of the supplier and the customer.

Typically, co-innovation is studied at a project level (Tuli, et al., 2007; Lagrosen, 2005). To fully understand how to manage co-innovation relationship portfolios, also with other partners than customers, longitudinal research efforts are needed that acknowledge the interactive and often networked nature of such collaboration. Also, the parties of co-innovation often change along the project. These swifts need to be examined closer in order to support their management. In addition, studies focusing on customers' experiences and benefits in different types of supplier-led coinnovation projects are called for in order to support these important relationships. This study offers some insight into possible customer selection criteria for the supplier's co-innovation projects. New studies, taking this view further, could contribute to the emerging research on prevailing the supplier's viewpoint into the characteristics of preferred customers. (e.g., Schiele, 2012) and customer attractiveness (e.g., Schiele et al., 2012) in context of co-innovation.

\section{Acknowledgements}

The authors wish to thank the anonymous reviewers and the editor for their insightful comments. In addition, we want to thank Katja Pääkkönen, Minna Oinonen, Ilkka Ojansivu and Jari Salo for their 
collaboration in the related research project. The financial support of the Finnish Funding Agency for Technology and Innovation in the early phases of this research is also gratefully acknowledged. 


\section{References}

Alam, I. (2002). "An Exploratory Investigation of User Involvement in New Service Development." Journal of the Academy of Marketing Science 30 (3): 250-261.

Alam, I. (2005). "Interacting with Customers in the New Product Development Process." In The PDMA handbook of new product development $\left(2^{\text {nd }}\right.$ ed.), ed. K. B. Kahn. Hoboken, NJ, USA: John Wiley \& Sons, Inc.

Athaide, G. A., and Stump, R. L. (1999). “A Taxonomy of Relationship Approaches During Product Development in Technology-Based, Industrial Markets." Journal of Product Innovation Management 16 (5): 469-482.

Athaide, G. A., R. L. Stump, and Joshi, W. A. (2003). "Understanding New Product Co-Development Relationships in Technology-Based, Industrial Markets." Journal of Marketing Theory \& Practice 11 (3): 46-58.

Backmann, J., Hoegl, M., and Parboteeah, K. P. (2016). "Cross-level Effects of Buyer-supplier Collaboration and Competition on Individual Gains and Individual Skill Utilization." Journal of Engineering and Technology Management 41: 14-25.

Biernacki, P. and Waldorf, D. (1981). "Snowball Sampling: Problems and Techniques of Chain Referral Sampling." Sociological Methods \& Research 10 (2): 141-163.

Blomqvist, K. (1997). “The Many Faces of Trust.” Scandinavian Journal of Management 13 (3): 271-286.

Bonner, J. M., and Walker Jr., O. C. (2004). "Selecting Influential Business-to-Business Customers in New Product Development: Relational Embeddedness and Knowledge Heterogeneity Considerations." Journal of Product Innovation Management 21 (3): 155-169.

Brito, R. P., and Miguel, P. L. (2017). "Power, Governance, and Value in Collaboration: Differences Between Buyer and Supplier Perspectives." Journal of Supply Chain Management 53 (2): 61-87.

Bruce, M., Leverick, F., Littler, D., and Wilson, D. (1995). "Success Factors for Collaborative Product Development:A Study of Suppliers of Information and Communication Technology." $R \& D$ Management 25 (1): 33-44.

Buur, J. and Matthews, B. (2008). "Participatory Innovation.” International Journal of Innovation Management 12 (3): 255-273.

Carbonell, P., A. I. Rodríguez-Escudero, and Pujari, D. (2009). "Customer Involvement in New Service Development: An Examination of Antecedents and Outcomes." Journal of Product Innovation Management 26 (5): 536-550.

Corsaro, D., and Snehota, I. (2011). "Alignment and Misalignment in Business Relationships." Industrial Marketing Management 40 (6): 1042-1054.

Cox, A. (2001), "Understanding buyer and supplier power: a framework for procurement and supply competence." The Journal of Supply Chain Management 37 (2): 8-15.

Cusumano, M. A. and Takeishi, A. (1991). "Supplier Relations and Management: A Survey of Japanese, Japanese-Transplant, and U.S. Auto Plants." Strategic Management Journal 12 (8): 563-588.

Davis, J. P., and Eisenhardt, K. (2011). "Rotating Leadership and Collaborative Innovation: Recombination Processes in Symbiotic Relationships." Administrative Science Quarterly 56 (2): 159-201.

Denzin, N.K., and Lincoln, Y. S. (2000). "Introduction: The Discipline and Practice of Qualitative Research." In Handbook of qualitative research ( $2^{\text {nd }}$ ed.), eds. N. K. Denzin, and Y. S. Lincoln. Thousand Oaks: Sage Publications. 
Dubois, A., and Gadde, L. (2002). "Systematic Combining: An Abductive Approach to Case Research." Journal of Business Research 55 (7): 553-560.

Enkel, E., Kausch, C. and Gassman, O. (2005a). "Managing the Risk of Customer Integration." European Management Journal 23 (2): 203-213.

Enkel, E., Perez-Freije, J. and Gassmann, O. (2005b). "Minimizing Market Risks through Customer Integration in New Product Development: Learning from Bad Practice." Creativity \& Innovation Management 14 (4): 425-437.

Eslami, M. H., and Melander, L. (2019). "Exploring Uncertainties in Collaborative Product Development: Managing Customer-supplier Collaborations." Journal of Engineering and Technology Management 53: 49-62.

Fang, E. (2008). "Customer Participation and the Trade-Off between New Product Innovativeness and Speed to Market." Journal of Marketing 72 (4): 90-104.

Fang, E., Palmatier, R. and Evans, K. (2008). "Influence of Customer Participation on Creating and Sharing of New Product Value." Journal of the Academy of Marketing Science 36 (3): 322-336.

Ford, D., Gadde, L-E., Håkansson, H. and Snehota, I. (2003). Managing Business Relationships. Wiley, Chichester.

Franke, N. (2006). "Finding Commercially Attractive User Innovations: A Test of Lead-User Theory."Journal of Product Innovation Management 23 (4): 301-315.

Füller, J., Hutter, K. and Faullant, R. (2011). "Why Co-Creation Experience matters? Creative Experience and its Impact on the Quantity and Quality of Creative Contributions." $R \& D$ Management 41 (3): 259-273.

Goldberg, J. M. and Schiele, H. (2020). "Innovating with Dominant Suppliers: Lessons from The Race For Laser Light.” International Journal of Innovation Management 24(1): 1-26.

Granovetter, Mark S. (1973). "The Strength of Weak Ties." American Journal of Sociology 78:136080.

Greer, C. R., and Lei, D. (2012). "Collaborative Innovation with Customers: A Review of the Literature and Suggestions for Future Research." International Journal of Management Reviews 14 (1): 63-84.

Gruner, K. E. and Homburg, C. (2000). "Does Customer Interaction Enhance New Product Success?" Journal of Business Research 49 (1): 1-14.

Hartley, J., Sørensen, E., and Torfing, J. (2013). "Collaborative Innovation: A Viable Alternative to Market Competition and Organizational Entrepreneurship." Public administration review 73(6): 821-830.

von Hippel, E. (1986). "Lead Users: A Source of Novel Product Concepts.” Management Science 32 (7): 791-805.

Kim, Y., and Choi, T. Y. (2015). "Deep, Sticky, Transient, and Gracious: An Expanded BuyerSupplier Relationship Typology." Journal of Supply Chain Management 51(3): 61-86.

Krolikowski, M., and Yuan, X. (2017). "Friend or Foe: Customer-Supplier Relationships and Innovation." Journal of Business Research 78: 53-68.

Lau, A. K. (2011). "Supplier and Customer Involvement on New Product Performance: Contextual Factors and an Empirical Test from Manufacturer Perspective." Industrial Management \& Data Systems 111 (6): 910-942.

Lau, A. K., Tang, E. and Yam, R. C. (2010). "Effects of Supplier and Customer Integration on Product Innovation and Performance: Empirical Evidence in Hong Kong Manufacturers." Journal of Product Innovation Management 27 (5): 761-777. 
Lagrosen, S. (2005). "Customer Involvement in New Product Development: A Relationship Marketing Perspective." European Journal of Innovation Management 8 (4): 424-436.

Lehtimäki, T., Oinonen, M., Ojansivu, I. and Salo, J. (2012). "Supplier and Customer Roles at Different Stages of Co-Innovation." Proceedings of the Annual 28th IMP Conference, Rome, Italy, September 13-15.

Lin, R. J., Chen, R. H., and Chiu, K. K. S. (2010). "Customer Relationship Management and Innovation Capability: An Empirical study." Industrial Management \& Data Systems 110 (1): 111-133.

Lüthje, C., and Herstatt, C. (2004). "The Lead User Method: An Outline of Empirical Finding: and Issues for Future Research." $R \&$ D Management 34(5), 553-68.

Manotungvorapun, N., and Gerdsri, N. (2019). "University-Industry Collaboration: Assessing the Matching Quality Between Companies and Academic Partners." IEEE Transactions on Engineering Management.

Miles, M. B., and Huberman, A. M. (1994). Qualitative Data Analysis: A Sourcebook of New Methods. Beverly Hills: Sage Pulications.

Noordhoff, C., Kyriakopoulos, K., Moorman, C., Pauwels, P. and Dellaert, B. (2011). "The Bright Side and Dark Side of Embedded Ties in Business-to-Business Innovation." Journal of Marketing 75 (5): 34-52.

Öberg, C. (2010). "Customer Roles in Innovations." International Journal of Innovation Management 14 (6): 989-1011.

Ombrosi, N., Casprini, E., and Piccaluga, A. (2019). "Designing and Managing Co-Innovation: The Case of Loccioni and Pfizer." European Journal of Innovation Management 22 (4): 600-616.

Oinonen, M., and Jalkala, A. M. (2015). "Divergent Goals in Supplier-customer Co-development Process: An Integrated Framework." Journal of Business \& Industrial Marketing 30 (3/4): 290301.

Prabhu, G. N. (1999). "Implementing University-Industry Joint Product Innovation Projects." Technovation, 19 (8): 495-505.

Rajalo, S., and Vadi, M. (2017). "University-Industry Innovation Collaboration: Reconceptualization." Technovation 62: 42-54.

Schiele, H. (2012). “Accessing Supplier Innovation by Being Their Preferred Customer.” ResearchTechnology Management 55 (1): 44-50.

Schiele, H., Calvi, R., and Gibbert, M. (2012). "Customer Attractiveness, Supplier Satisfaction and Preferred Customer Status: Introduction, Definitions and an Overarching Framework." Industrial Marketing Management 41 (8): 1178-1185.

Slowinski, G., Sagal, M., Williams, K., and Stanton, T. (2015). "Reinventing Supplier Innovation Relationships." Research-Technology Management, 58 (6): 38-44.

Scaringella, L., Miles, R. E., and Truong, Y. (2017). "Customers Involvement and Firm Absorptive Capacity in Radical Innovation: The Case of Technological Spin-Offs." Technological Forecasting and Social Change, 120, 144-162.

Schweitzer, F., Van den Hende, E. A., and Hultink, E. J. (2019). "There's More Than One Perspective to Take into Account for Successful Customer Integration into Radical New Product Innovation: A Framework and Research Agenda." IEEE Transactions on Engineering Management.

Tangpong, C., Michalisin, M. D., Traub, R. D., and Melcher, A. J. (2015). "A Review of BuyerSupplier Relationship Typologies: Progress, Problems, and Future Directions." Journal of Business \& Industrial Marketing, 30 (2): 153-170. 
Tran, M. K., and Shiu, E. (2015). "User-Innovator Typologies in Co-Innovation: From Creativity to Reality." ISPIM Conference Proceedings, Manchester: 1-11.

Tsou, H.-T., Cheng, C.C.J. and Hsu, H.-Y. (2015) "Selecting Business Partner for Service Delivery Coinnovation and Competitive Advantage." Management Decisions 53 (9): 2107-2134.

Tuli, K. R., Kohli, A. K. and Bharadwaj, S. G. (2007). "Rethinking Customer Solutions: From Product Bundles to Relational Processes." Journal of Marketing 71 (3): 1-17.

Urban, G. L., and E. von Hippel, E. (1988). "Lead User Analyses for the Development of New Industrial Products." Management Science 34 (5): 569-582.

Wang, L., and Li, J. (2017). "The Antecedents and Innovation Outcomes of Firms' Absorptive Capacity in Global Buyer-Supplier Relationships." The Journal of Technology Transfer, 42 (6): 1407-1430.

Wilson, D., Littler, D., Leverick, F. and Bruce, M. (1995). "Collaborative Strategy in New Product Development - Risks and Rewards.” Journal of Strategic Marketing 3 (3): 167-188.

Xue, X., Zhang, X., Wang, L., Skitmore, M., and Wang, Q. (2018). “Analyzing Collaborative Relationships Among Industrialized Construction Technology Innovation Organizations: A Combined SNA And SEM Approach." Journal of Cleaner Production, 173, 265-277.

Yin, (2009). Case Study Research: Design and Methods. Thousand Oaks (Calif.): Sage Publications. 